Southern Illinois University Carbondale

OpenSIUC

Publications

Department of Geography and Environmental

Resources

$11-2010$

\title{
A Pragmatic Assessment of Government Support for Organic Agriculture in Ireland
}

Leslie Duram

Southern Illinois University Carbondale, duram@siu.edu

Follow this and additional works at: http://opensiuc.lib.siu.edu/gers_pubs

This is an Author's Accepted Manuscript of an article published in Irish Geography, Vol. 43, no. 3

(November 2010).

Copyright Taylor \& Francis, available online at: http://www.tandfonline.com/0.1080/

00750778.2011 .583138 .

\section{Recommended Citation}

Duram, Leslie. "A Pragmatic Assessment of Government Support for Organic Agriculture in Ireland." (Nov 2010).

This Article is brought to you for free and open access by the Department of Geography and Environmental Resources at OpenSIUC. It has been accepted for inclusion in Publications by an authorized administrator of OpenSIUC. For more information, please contact opensiuc@lib.siu.edu. 
Irish Geography Vol. 43, No. 3, November 2010, pages 269-283

A Pragmatic Assessment of Government Support for Organic Agriculture in Ireland

\author{
Leslie A. Duram
}

Southern Illinois University, Carbondale, Illinois USA

Leslie A. Duram (former Fulbright Scholar, NUIG, Geography, 2009/2010)

Current: Professor and Chair, Department of Geography, SIU, Mailcode 4514, Carbondale, IL 62901, USA. Email: Duram@siu.edu

(Received 4 October 2010)

Drawing on a pragmatic approach, this paper provides an analysis of governmental support for organic farming in Ireland. There are varying levels of encouragement and programmes provided to farmers in their conversion from conventional to organic production, and in their maintenance of organic production. Support policies vary across regions and are linked to European Union legislation, thus it is challenging to document the many types of support in place. This research investigates relevant technical, financial, and policy support available to organic farmers in Ireland. This exploratory study develops an assessment of Ireland within eight key categories of organic agricultural support: leadership, policy, research, technical support, financial support, marketing and promotion, education and information, and future developments. Information and data from the Irish Department of Agriculture, Fisheries and Food (DAFF), the Irish Agriculture and Food Development Authority (Teagasc), and other governmental and semi-governmental agencies were utilized to assess the level of support in each category. Following the pragmatic approach, this assessment provides key findings which allow policymakers, organizations and citizens to better understand the current situation and set a path for the future development of organic farming in Ireland.

Keywords: Irish agriculture, organic agriculture, organic farming, policy, pragmatism 


\section{Introduction}

Organic foods are increasingly popular, as consumers perceive of and seek environmental and health benefits from these produce, grains, dairy, and meats. At the same time, some farmers are attracted to organic methods, either as new entrants into agriculture, or as a seasoned producer shifting to "new" organic methods. In either case, consumer demands are pushing organic markets, but currently the agricultural sector is lagging behind in terms of supply. This is perhaps a unique situation, which begs the question: What would encourage more farmers to transition to organic methods? This paper investigates the possible opportunities for supporting organic farmers, using a case study of Ireland. Support may come in the form of technical advice, financial payments, and informational campaigns, to name a few. Specifically, this paper uses a pragmatic approach to gather "real world" information from numerous governmental and non-governmental sources to provide an understanding of current support and suggest future activities that would encourage organic agriculture among Irish farmers.

\section{Pragmatism and Geography}

A pragmatic research approach allows for applied research, which is particularly useful in the assessment of current government programmes from a geographic perspective. Pragmatism is a "philosophy of engagement" that "promotes an open-mindedness to ideas whose usefulness is ultimately determined through practical applications" (Wood and Smith 2008, p. 1527). Current complex social and/or ecological networks and sustainability issues are to be investigated holistically, as it accepts a systems approach, not a linear investigation that seeks one resultant "truth." There is on-going interest in linking pragmatism to geography (Cohen 2006, Hepple 2008; Barnes 2008). 
To understand current collaboration between pragmatic and geographic research, it is necessary to look at the historical foundations of pragmatism. This philosophy is fundamentally concerned with understanding problems in the real world. Indeed pragmatism “... turns away from abstraction and insufficiency, from verbal solutions, from bad a priori reasons, from fixed principles, closed systems, and... the pretense of finality in truth." (James 1907, p. 51) Instead, pragmatism "defines meaning and knowledge in terms of their function in experience" (Beck 1969, p. 515). In addition, pragmatism seeks to understand the multiple factors involved in people's actions in a given situation (Castle 1996). Further, pragmatic research is utilized as a means of problem solving and for the promotion of human welfare (Frazier 1981, White 1972).

Research within the pragmatic tradition: accepts complexity in human and ecological dynamics and is guided by human experience as the basis of understanding a complex problematic situation (Duram 1997, Light and Katz 1996, Wescoat 1987, 1992). According to Dewey, a key pragmatic scholar, experience is what we do, how we learn, and what happens to us (Cutchin 2008, Thayer 1970, Dewey, 1958). Another key pragmatist, Charles Peirce, noted that we should look at general long term effects, not just short term events (Oehler 1968). Pragmatism focuses on tangible human experiences in a setting where knowledge is valued for its usefulness (Charon 1979). Recent work, for example, uses the concept of "pragmatic localism" to investigate how national policies are best implemented at the local level (Coaffee and Headlan 2008).

Drawing from these previous works in alternative agriculture and geography, the pragmatic approach draws on several themes that are relevant to this paper. First, a systems approach describes the interrelationships between humans and the environment, which is key for the studying the ecological and social aspects of organic farming. Second, problems are broadly viewed as complex "problematic situations;" so policy, economics, ecology, and community are all 
part of the solution to supporting organic farmers. Third, human experience is often the basis for understanding a given situation, so farmers are considered not as purely economically rational decision-makers, but rather as complex beings with multiple motivations. Finally, pragmatism promotes social activism and policy formulation. This paper, then, presents a pragmatic investigation of the complex, interrelated elements of support for organic agriculture in Ireland and seeks to understand the current situation. The goal is to assess an evolving governmental support system and suggest possible actions for future organic farming support in Ireland.

\section{Organic Agriculture in Ireland}

Soil health is the basis of organic farming, which produces diverse crops without the use of synthetic pesticides and fertilizers inputs. Organic certification involves a conversion period of 2 to 3 years, annual inspections, and distinct marketing channels (EU 2009, EC 1991, USDA 2009, Duram 2009). Both US and EU markets for organic products have grown significantly in recent decades (Dimitri and Oberholtzer 2005, Willer and Kilcher 2009). Still, there is geographical variation among the level of adoption of organic methods (Organic Europe 2010). For example, within the EU, Austria leads the way with over $18 \%$ of farmland in organic production; Sweden, Estonia, and Latvia have approximately 10\%, while Malta, Romania, Bulgaria and Ireland are $1 \%$ or below (Organic World 2009). Research indicates the ecological benefits of organic crops are apparent in numerous research findings (Altieri 1995, Mäder et al. 2002, Bengtsson et al. 2005, Reganold et al. 2010).

In Ireland, the Programme for Government indicates a national plan to convert a minimum 5\% of acreage to organic farmland by 2012. The Organic Farming Action Plan 20082012 was developed by a steering committee led by the Department of Agriculture, Fisheries and 
Food and includes four main goals: increase organic production to keep pace with consumer demand; increase information and training; develop organic markets; and increase public procurements of organic products. The plan is comprehensive and far-reaching, with over 60 action goals and four key objectives: 1 . increase organic production to keep pace with consumer

demand; 2. increase information and training; 3 . develop organic markets; and 4. increase public procurements of organic products (DAFF 2009). Indeed this action plan is necessary because of the significant strides needed to reach the government's goal of 5\%-- currently only $1.2 \%$ of utilizable agricultural land is in organic production. Thus, in two years time, this land use must increase four-fold. There is clearly demand for such increases, as an estimated $75 \%$ of organic produce is imported to Ireland (Bord Bia 2009).

Looking to the future, the key challenges in encouraging farmers to shift from conventional to organic methods include information, training, and funding. In unison, these are referred to as 'government support.'

\section{Types of Government Support for Organic Farming}

Research indicates that farmers are faced with significant obstacles when converting to organic agricultural methods: cost and risk associated with changing to a new way of farming, finding ways to market specialized products, and obtaining relevant information and technological support (Greene and Kremen 2003). Farmers have various motivation for converting to organic, and these reasons vary spatially and temporally (Padel 2008). Particularly because organic farming is based on diversification and market niches, decisions are fully in the hands of individual, independent farmers (Beus and Dunlop 1990, Ikerd 2001). Major barriers facing organic farmers include lack of stable markets and lack of organic farming research information 
(Duram 1999). In the US, particularly, other challenges farmers face include an inability to receive crop insurance, lower subsidy payments because of diversified crops, lack of access to allowable inputs, and not receiving premium prices for the three year transition period (Walz 1999). Additionally, many of the potential social and environmental benefits provided by organic production methods remain unrewarded governmental programmes, which are often only available for a short timeframe or which may be at the political will of any given administration (Lampkin and Padel 1994, Lotter 2003).

In order to provide relevant support to organic farmers, it is necessary to understand their personal characteristics and decision-making influences, which are both complex and individualized (Lockeretz 1997, Hanson 2004, Darnhofer et al. 2005). Organic farmers are willing to accept new ideas, enjoy the challenges that organic farming offers and the job satisfaction it provides, and more actively seek information sources (McCann et al. 1997, Duram 2005). Organic farming does not fit the classic model of diffusion/adoption, but has moved more slowly because organic farmers must develop new techniques and share information among themselves (Padel 2001). In fact, farmers who quit farming organically often do so because they lack marketing support and information sources (Rigby et al. 2001).

Organic farmers rank "lack of information and personal experience" as a significant challenge to converting to organic production methods (Walz 1999). Furthermore, Lockeretz (1997) found that farmers who use little or no chemicals need more information in order to implement these alternative production practices. Organic farmers receive information from a wide variety of sources. Some of these sources are similar to the sources used by conventional farmers, but many others are not. Organic farmers rely less on public sources of information than private sources, like other farmers, certifying agents, input suppliers, books, and group 
activities (Walz 1999, Duram and Larson 2001, Lohr and Park 2003, Hanson et al., 2004).

Public agencies, such as extension services should use this to their advantage to create information networks and catalog information sources for farmers in a particular region (Lohr and Park 2003). Many organic farmers preferred workshops over publications and field days and organic farmers are very interested in a long-term study on organic production methods specific to local conditions (Delate and Dewitt 2004).

In 1997, a survey conducted by the Organic Farming Research Foundation (OFRF) found that organic farmers found most conventional extension agents to be a barrier to production rather than a useful source of information (Lipson 1997). Indeed, there is a close attitudinal alignment between government extension agents and conventional farmers (Egri 1999). This can hinder the ability of conventional extension agents to give sound advice to organic farmers. In a study by Duram and Larson (2001) organic farmers ranked state departments of agriculture and the United States Department of Agriculture (USDA) as the least used sources of information. The study found that organic farmers use few, if any, government sources of information. Overall, then, organic farmers need relevant, regionally specific information and assistance, but this support appears to be lacking.

\section{Method of Analysis}

Drawing from a pragmatic approach, this research analyses current data from multiple governmental and non-governmental sources to discover the real world situation regarding support for organic agriculture in Ireland. Public information sources were tapped: DAFF, Teagasc, Bord Bia, Organic Trust, Irish Organic Farmers and Growers Association, the Organic Center, and other relevant websites. Interviews (identity anonymity preserved) with key experts 
were also conducted. Previous research suggested a categorical framework may be utilized to assess support for organic agriculture at the state (i.e., province, county) level (Bloom and Duram 2007). Developing this categorical framework, here the case study of Ireland provides the opportunity for analysis at the national level. Thus this research outlines the main types of support, notes the fulfillment of these activities, and also the shortfalls of these possible actions in terms of Irish organic agriculture.

\section{Pragmatic analysis of Organic Support in Ireland}

In the Irish context, the support framework is comprised of eight main categories: Leadership, Policy, Research, Technical Support, Financial Support, Marketing and Promotion, Education and Information, and Future Development (Table 1).

Leadership. The first category is leadership, which is comprised of a vision, and goals that encourage organic agriculture. Another factor within this category is the presence of an advisery board, which typically includes stakeholders from various aspects of the organic agricultural community. The final component within the leadership category is an inter-agency collaboration to promote organic agriculture.

The Minister of State for Food and Horticulture, at the Department of Agriculture, Fisheries and food, Mr. Trevor Sargent T.D., had been influential. His guidance and emphasis on the organic sector clearly influenced activities across the country. The National Steering Group for the Organic Sector is comprised of 29 experts from various backgrounds in the agriculture, food and business sectors. They developed the Organic Farming Action Plan (20082012) which presents a comprehensive set of goals and actions to promote organic agriculture in 
Ireland. According to this plan, there are four objectives: increase organic production to keep pace with consumer demand; increase information and training; develop organic markets; and increase public procurements of organic products. There are over 60 specific tasks listed in the plan, with the relevant agency indicated that will take the Lead Role and Supporting Role in following through on the actions. Further, the Actions are all delineated as short or medium term goals, which prioritize and synchronize the various activities (Department of Agriculture 2009). In July 2009, Minister Trevor Sargent announced the formation of Forás Orgánach, a new group established to drive forward the development of the organic sector in Ireland. Forás Orgánach replaces the National Steering Group for the Organic Sector which recently completed its second three-year term. In February 2011, Trevor Sargent stepped down as Minister of State for Food and Horticulture (RTÉ 2010). Given that he had been such a fervent supporter of organic farming, his resignation left many questioning the future national commitment to organic agriculture in Ireland. Still, in terms of leadership, there is a high level of inter-agency activity and coordination of organic agricultural activities. Specifically, DAFF, Teagasc, and Bord Bia are the lead agencies and semi-governmental organizations that work in unison to support organic farming in Ireland.

Policy. The second main category in the framework is policy, which includes legislation, and rules related to organic agriculture, as well as enforcement of these rules. This includes monitoring national and international organic policies and observing of the status of organic farming within the state. The existence of approved organic programmes and certification standards provide the state with the authority to enforce the production and certification requirements of the governing bodies. 
In the Irish context, European Union regulations are the overarching rules. Specifically, EEC No 2092/91 and Council Regulation 1804/99 provide clear rules governing the production of organic food. There are detailed requirements for agricultural products that can be labeled 'organic' and the rules define the methods of production, the labeling, processing, inspection and marketing of organic products in EU countries (as well as the importation of organic production into EU countries). In Ireland, DAFF oversees the organic sector and ensures that the EU regulations are met. This national and international synchronization is a key component of the policy category. The EU allows for member states to use private inspection bodies to certify organic production and processing and in Ireland there are two main bodies for food and livestock: the Irish Organic Farmers and Growers Association (IOFGA) and the Organic Trust Ltd. At the current time, Irish agricultural policy is in flux as the Rural Environment Protection Scheme (REPS) was closed to new applicants and the new Organic Scheme was just introduced in early 2010.

Research. The third major assessment category is research, which could be promoted and undertaken by several governmental organizations. For example, the main entities conducting agriculture research may be the universities, or extension agencies. A comprehensive research programme should be built on a network of public agencies and non-governmental agencies, but must be farmer-driven, so the results are relevant to their on-farm demands.

There is no college degree in organic agriculture in Ireland, although students could study general agriculture and take courses on organic methods at a few locations. There is relatively little university based research into organic farming in Ireland. Instead, Teagasc assumes that role and often teams up with university personnel. There are few grants for research, other than 
the joint projects with Teagasc. Farmer initiated research is independent and can be very useful, as seen in the US (Duram 2005) but this type of research is not funded through the Irish government at this time. There are three Teagasc research centres (in Athenry, Wexford and Carlow) which carry out various research projects on state owned and leased land. These projects are used in conjunction with training and courses offered on organic methods. Future plans indicate that Teagasc will be conducting more on-farm research projects located on active organic farms.

Technical Support. The fourth main category is technical support, which has seven subcategories. The first is department of agriculture personnel with duties specifically addressing organic agriculture. Other areas include assistance to growers in negotiating the certification process, evaluating organic as a production option, developing sound business practices, and whole farm planning to manage pests, weeds, crop rotations, and soil building. Technical assistance also includes helping farmers through the two-year conversion period as they shift from conventional to organic production methods. Technical assistance includes training of agricultural advisers and farmers on organic farming methods.

There are several components to technical support. First, is the presence of four organic specialists from Teagasc in Ireland; distributed across the country. Second is the role of certification agencies in informing farmers about the certification process; here IOFGA and the Organic Trust play a role. Third, is helping farmers evaluate the option of organic conversion; this is accomplished through Teagasc local advisers and private agricultural consultants, although this complicated by the fact that farmers may have to pay for their services. Still advisers and consultants typically assist conventional farmers on environmental topics and they 
can then mention organic methods as an option. Next, once a farmer is interested, the adviser or consultant can help them develop a conversion and/or business plan. Fifth, transition programmes assist farmers during the conversion process. Sixth, training is a key component of support and this is a focus area for Teagasc, which runs six courses at various locations around the country, several times a year. The courses are: 1) Introduction to Organic farming; 2) Organic Drystock production; 3) organic Crop production; 4) Organic Dairying; and 5) Introduction to Organic Poultry Production (Teagasc 2008). Training also includes the day to day assistance of farmers by the various Teagasc personnel, the on-farm tours and open days, Farm Walks and other events to showcase existing organic farms. Teagasc staff work to assist farmers develop specific farm plans to address pest and soil building. Pesticide drift has not been addressed with buffer areas in Ireland, although split conventional/organic operations must produce different crops using the various methods.

Financial Support. The fifth category is financial support. This support might be direct payments to farmers based on their certified organic acreage. It may come in the form of costshare programmes for certification and conversion periods. Financial support may include loans, grants or insurance assistance, because many organic farmers do not qualify for the typical conventional programmes.

The financial support for organic farmers in Ireland has been quite significant. The Organic Scheme has been on hold until January 2010, but it should continue along similar lines. Funds are provided for the 2 year conversion: $€ 212$ per hectare for farms 3 to 55 ha, this is reduced to $€ 106$ per ha for years $3-5$. Rates are lower for larger land holdings. Still this indicates significant monetary support for organic farmers. Certification costs are not covered in 
grant funding. There are important grants available to farmers for equipment, buildings, and offfarm investments necessary in the production shift to organic methods, although these grand are currently suspended. There are no specific loan programmes available to organic farmers in Ireland, which can be a concern. Specifically because their production techniques require some land be left in fallow (ley), banks sometimes view this as non-productive land use and would be less likely to grant a loan. Insurance is offered only as is provided to conventional Irish growers

Marketing and Promotion. The sixth category is marketing and promotion, with an emphasis on linking growers and processors, as well as growers and consumers. This can be done by facilitating joint marketing ventures and production contracts, hosting tradeshows, studying consumer demand and preferences, and creating databases of growers, processors, and distributors. Farmers may need assistance in developing their own marketing strategies and making connections locally, regionally and even globally.

From an international perspective, the EU takes the initial step in promoting organic products with its 'Good for Nature, Good for You' slogan on their agriculture website for organics. This unified slogan has been very beneficial to organic markets in Ireland, as it provides a deep reason to purchase organic products, that supercedes price concerns (Bord Bia Expert 2009). In Ireland, Bord Bia is the primary agency responsible for the promotion and marketing of food, and thus organic food. In recent years, Bord Bia has focused on promoting an annual Organic Week, which showcases these foods and draws attention to local markets.

Bord Bia also conducts research on consumer demand and preferences. For example the comprehensive "Ethics, Emotions and Organic Food" report from October 2008, which surveyed 1,000 shoppers about their attitudes toward organic food. Interestingly, this research found a 
group of committed 'core buyers' who buy organic frequently, particularly vegetables, fruits and yogurt. These shoppers are willing to pay an additional $10 \%$ price premium over conventional food (Bord Bia 2008). Note this is down from the $20 \%$ noted in 2000. There is representation at trade shows, notably for the first time in 2009 Bord Bia exhibited a full display of organic food at the BIOFACH, organic trade fair in Nuremberg, Germany. BioFach is the world's largest global organic event with over 46,000 trade visitors from 130 countries.

On the other hand, Bord Bia states that they will do any sort of market development when requested. Finally, in terms of domestic market development, Bord Bia has initiated an innovative programme to educate children about fruits and vegetables: incredibleedibles.ie. An information packet was sent to all National schools with information, a DVD, and a kit to begin a school garden; fully $2 / 3$ of schools have begun to implement this programme. This will lead to future vegetable shoppers in upcoming generations. Still, organic farmers need marketing assistance at the local, regional, national, and international levels. This is not evident in the Ireland example. It seems that if farmers have a specific question, they may find help, but if they are more vaguely interested in adopting organic methods, they may not feel encouraged by a lack of established marketing programmes.

A distributor listing of organic processors is held by IOFCA, but not by the DAFF or Bord Bia, which may be a barrier for organic farmers to contact possible distributors. Likewise, there is no national certified organic producers list, except for information provided by the NGOs (certification agencies). This lack of streamlined data availability may inhibit growth in the organic market. 
Education and Information. The seventh category is education and information sources, which is comprised of educating conventional farmers on the benefits and opportunities for conversion, and educating current organic producers about new production methods. This is often accomplished through websites, workshops, courses, demo sites, and written materials. It could be in the form of a mentor programme that connects new organic producers with more experienced producers or a comprehensive information network. Information on certification can come in many forms, including internet sources, but should include a list of accredited certification agencies.

Most of the specific subcategories for support in this area are accomplished by Teagasc and the DAFF, which some assistance from the certification bodies and NGOs. Notably, workshops, courses and Farm Walks are all part of the Teagasc organic activities accomplished by their four Organic Specialists (Teagasc 2008)). Specifically, the internet is a significant source of information on organic agriculture, with the following websites of crucial importance:

1) Department of Agriculture, Fisheries and Food, 'Organic Farming'/ An Roinn Talmhaíochta, Iascaigh \& Bia: http://www.agriculture.gov.ie/organics/

2) Teagase/ Irish Agriculture and Food Development Authority. 'Organic Farming' http://www.teagasc.ie/topics/organicfarming/

3) Bord Bia/ Irish Food Authority. www.bordbia.ie And specifically for organic food: http://www.bordbia.ie/aboutfood/organicfood/Pages/OrganicFood.aspx

On the DAFF Homepage, organic farming is mentioned once, at the bottom under 'Rural Environment' which may be a bit hidden for farmers seeking information. Indeed it emphasizes the funding aspect of organic agriculture, but deemphasizes the business aspects of production. On the Teagasc website, however, there is no information on organics on the initial Homepage, rather one must intentionally seek out the term 'organic farming' from the pull-down menu of 
'Topics.' This could be remedied to make organic information more prominent on the webpage. On the Bord Bia Homepage, several things draw attention to organic foods. First, there is a colorful graphic announcing the 'Organic Gardening for Primary Schools' programme which notes that teachers and pupils can plan, build, develop and maintain a school garden using organic principles. The National Organic Awards are presented as a Press Release, and National Organic Week is noted, all of which draw attention to organic food.

In addition, the certification agencies and NGOs play an important role in education and providing information on organics:

1) Irish Organic Farmers and Growers Association Ltd. www.irishorganic.ie

2) Organic Trust Ltd. www.organic-trust.org/

3) The Organic Centre www.theorganiccentre.ie

IOFGA and the Organic Trust are the two certification agencies, which also send representatives to various Farm Walks and trains held by Teagasc. The Organic Centre is an independent organization that promotes "organic gardening and sustainable living through training, demonstration and the provision of information." (Organic Centre 2010). Finally, Drumcollogher, Organic College in Limerick, An t-Ionad Glas, is a private school offers initial advice and one-day courses in organic gardening, featuring tours of their organic gardens (An tIonad Glas 2009).

Future. The eighth category assesses plans for future organic agricultural initiatives. This is open to a variety of activities a state is planning to implement, but either has not received funding or has not progressed for other political reasons.

There are significant goals to advance organic farming in Ireland: indeed 5\% of utilizable agricultural land is to be in organic production within three years (DAFF 2008). Such 
a steep increase presents a huge challenge. Yet, with the current strategic plan, support from the Minister and government attention to organic farming, we can assume the future should be bright. There is media attention and a popularity or trendiness among some shoppers. On the other hand, the economic recession is a great unknown factor, which could influence consumers for several years. Even if demand remains high, the issue of supply is of concern. The number of organic farmers in Ireland remains low and the percentage land area is very low among EU nations. There have been more applications for certification in the past year, which may indicate a new trend in production. Still there is a huge need and growing demand for organic production-particularly cereals. In addition to domestic markets, there is a huge market potential in the UK, where organic demand remains high and consumer research indicates the existence of a very positive image of Irish food products.

Clearly, the situation in Ireland is currently in flux as the Rural Environment Protection Scheme (REPS) is closed to new applicants and the new Organic Scheme was unveiled in January 2010. Changes in the Ministry of Agriculture also imply possible de-emphasis on organic agriculture. With these new rules, farmers and agricultural advisers are working to implement the new programmes. After a time, researchers will be able to analyse the effect of the programmatic changes on the conversion to organic methods. This will provide an even richer context for additional research based on categories in the framework.

\section{Discussion and Conclusion}

Overall, this assessment framework details the comprehensive activities that could be undertaken to support organic agriculture. This framework may be used to compare the level of support in 
different regions, to determine areas for expansion, and to encourage policy makers to target necessary programmes.

Following the pragmatic tradition, this research seeks to make suggestions that contribute to improving the context for organic farming in Ireland. There are many positive aspects to the support that has been provided to the organic industry in Ireland, yet there is room for improvements. Based on the framework developed here, two things become apparent.

First, there is a conflict between the strong support in the leadership and policy categories, but the lag in terms of farmers' actual adoption rates. In other words, it appears that there has been an atmosphere of encouragement for organic farming, but this has not been fully realized in the agricultural sector. Here, we must question the authenticity of the government leaders and their follow through. It is not enough to promise funding and programmatic changes. Farmers and advisers need to see long term commitment and fundamental changes in the DAFF in order to feel comfortable in making the conversion to organic methods. Somehow the political 'speak' has not been very convincing.

Second, NGOs, are expected to do a great deal of work in supporting organic agriculture in Ireland. While this is, potentially, a positive step that ensures an independent organic movement, there are some pitfalls. For example, NGOs are typically underfunded and may be unable to provide consistent assistance to farmers. Secondly, NGOs may vary regionally which may lead to inconsistency in national goals. So, the fact that The Organic Trust and IOFGA must do a great deal of education, may lead to long term lags in consistent transfer of information. Further, the fact that these NGOs maintain the only list of growers, is a detriment to the organic marketing system. This places a larger burden on NGOs which should be relegated 
to Bord Bia or DAFF. At the least, government funding for these key NGOs should be higher and stable in the long term.

On the other hand, one key facet of support for organic farming is the interaction, collaboration, and networking that exist between agricultural professionals, businesses, researchers, and some organic farmers. This is evident in Ireland, as the key agencies and NGOs work in unison, and this should lead to programmes that are tailored to the ever-changing needs of the organic industry. In this enabling environment, agriculture professionals who are interested in organic agriculture can make it more of a priority and create more opportunities for farmer support. It is important that agriculture professionals and organic advisery boards continually monitor the needs of the organic industry and adjust support accordingly. Incorporating farmers in the decision-making process ensures that their needs are addressed and provides most effective support.

In addition, it is critical that Ireland continue its commitment to organic agriculture by maintaining the four organic advisers from Teagasc. These four experts, responsible for different regions of the country provide invaluable information to farmers and their communities. They organize and provide courses on organic methods, training sessions, and farm walks. These activities are critical to the continued success of organic farming, and the possible expansion of organic acreage, as more farmers may be exposed to these methods. In the words of one farmer: "I always learn a lot" at the Farm Walks. Another farmer described their Teagasc Organic Adviser as: "ready to help at any time."

Determining types of support to be provided to organic producers can be difficult for agriculture professionals because the needs of organic farmers are very different from conventional farmers. The assessment framework developed here provides a useful tool for 
determining what support exists and what areas need improvement. It can also be used as a mechanism for sharing ideas among agencies and improving the overall acceptance of organic agriculture.

Future research paths include fine-tuning the framework and applying it in diverse settings. First, the framework could be edited and additional categories may be deemed necessary. Based on long term trends in Ireland, research may indicate the need to alter of the framework. In addition, further analysis could assist in development of a "weighting" system with scores given in particular categories of support. And if there is a specific goal in mind, or specific needs in one region, this assessment tool could incorporate that into a scoring system. Second, this assessment tool is broadly applicable and could be utilized to analyse the status organic agriculture in other nations. Likewise, it could be 'downscaled' to study a local foodshed and discover what may be applicable in a community context.

In the Irish context, there is a paradoxical situation that is both positive and negative. On the one hand, it appears that overall the support for organic agriculture in Ireland is in place, but on the other hand, there is a very slow rate of adoption of organic methods. Much more needs to be done to reach farmers and encourage them to convert to organic methods. A significant barrier seems to be farmers' negative perceptions of organic and their concern that organic conversion is too difficult and outside the norm of agriculture. It is, in the pragmatic sense, outside their 'practical range of choice.' (Wescoat 1987). Possible actions include: fine-tuning information sources to meet farmers' needs and expectations; and addressing the social stigma of organic production among many conventional farmers. Clearly there needs to be a long-term plan to convince conventional farmers that organic conversion is possible, provides an opportunity, and can be a successful means of production. 
In conclusion, this paper exemplifies the opportunity of a pragmatic research approach; in this case, a comprehensive analysis of the organic agricultural system. By understanding the context of organic farming and food, and applying contextual data to build an assessment framework, the results can be helpful in providing 'real world' suggestions for building a viable organic food system. 


\section{References}

Altieri, Miguel A. 1995. Agroecology: The Science of Sustainable Agriculture, 2nd ed. Boulder, CO:Westview Press.

An t-Ionad Glas. 2009. Organic College, Drumcollogher, Co Limerick. Tel: (063) 83604. Email: oifig@organiccollege.com. www.organiccollege.com

Barnes, Trevor J. 2008. American pragmatism: Towards a geographical introduction. Geoforum 39: Pages 1542-1554

Beck, R.N. 1969. Perspectives in Philosophy. Holt, Rinehart \& Winston, New York, N.Y.

Bengtsson, Janne, Johan Ahnstrom, and Ann-Christin Weibull. 2005. "The effect of organic agriculture on biodiversity and abundance: a meta-analysis." Journal of Applied Ecology 42: 261-69.

Beus, Curtis E. and Riley E. Dunlop. 1990. Conventional Versus Alternative Agriculture: The Paradigmatic Roots of the Debate. Rural Sociology 55(4): 590-616.

Bloom, S. and L.A. Duram. 2007. A Framework to Assess State Support of Certified Organic Farming. Journal of Sustainable Agriculture 30(2):105-124.

Bord Bia. 2008. Ethics, Emotions and Organic Food. Bord Bia, Irish Food Board. October 2008. www.bordbia.ie.

Bord Bia. 2009. Horticulture Business Specialist, Bord Bia. Personal interview: 22.10.09.

Castle, E. 1996. A pluralistic, pragmatic and evolutionary approach to natural resource management. In A. Light and E. Katz (eds.) Environmental Pragmatism. Routledge, London, England. pp. 231-250

Charon, J.M. 1979. Symbolic Interactionism. Prentice Hall, New York, N.Y.

Coaffee Jon, and Nicola Headlam. 2008. Pragmatic localism uncovered: The search for locally contingent solutions to national reform agendas. Geoforum 39: 1585-1599

Cohen, M. 2006. The roots of sustainability science: a tribute to Gilbert F. White. Sustainability: Science, Practice, \& Policy 2(2):1-3. http://ejournal.nbii.org/ archives/vol2iss2/editorial.cohen.html.

Cutchin, Malcolm P. 20078 John Dewey's Metaphysical Ground-Map and its Implications for Geographical Inquiry. Geoforum 39: 1555-1569.

Dewey, J. 1958. Experience and Nature. Dover, New York, N.Y. 
Darnhofer, I., W. Schneeberger, B. Freyer 2005. Converting or not converting to organic farming in Austria: Farmer types and their rationale. Agriculture and Human Values, 22: 39-52.

Delate, Kathleen, and Jerald Dewitt. 2004. Building a farmer-centered land grant university organic agriculture programme: A Midwestern partnership. Renewable Agriculture and Food Systems 19(2):80-91.

DAFF. 2008. “Organic Farming Action Plan 2008-2012.” Irish Department of Agriculture, Fisheries and Food: An Roinn Talmhaíochta, Iascaigh \& Bia. Accessed 21/10/09 at: www.agriculture.gov.ie/media/agricultureie/farmingsectors/organic/OrganicFarmingActi onPlan.pdf

Dimitri, Carolyn and Lydia Oberholtzer. 2005. Market-Led Versus Government-Facilitated Growth: Development of the U.S. and EU Organic Agricultural Sectors, WRS-05-05, USDA, Economic Research Service, August 2005. http://www.ers.usda.gov/publications/wrs0505/

Duram, L. 1997. A pragmatic study of conventional and alternative farmers in Colorado. Professional Geographer 49(2):202-213.

Duram, Leslie A. 1999. Factors in organic farmers' decision-making: Diversity, challenge, and obstacles. American Journal of Alternative Agriculture 14(1): 2-10.

Duram, Leslie A. 2005. Good Growing: Why Organic Farming Works. Lincoln, NE: University of Nebraska Press. 250 pp.

Duram, Leslie A. 2009. The Encyclopedia of Organic, Sustainable, and Local Food. ABCCLIO/Greenwood (Praeger): Santa Barbara, CA.

Duram, Leslie A., and Kelli L. Larson. 2001. Agriculture Research and Alternative Farmers' Information Needs. Professional Geographer 53(1):84-96.

EC. 1991. 'Council Regulation (EEC) No 2092/91 of 24 June 1991 on Organic Production of Agricultural Products, Official Journal of the European Communities, Vol. L198, pp.115.

Egri, Carolyn P. 1999. Attitudes, Backgrounds, and Information Preferences of Canadian Organic and Conventional Farmers: Implications for Organic Farming Advocates and Extension. Journal of Sustainable Agriculture 13(3): 45-73.

EU. 2009. Organic Farming: Good for Nature, Good for You. European Commission, Agriculture and Rural Development, Organic Farming. http://ec.europa.eu/agriculture/organic/home_en

Frazier, J. 1981. Pragmatism: geography and the real world. In M. Harvey and B. Holly (eds). Themes in Geographic Thought. Croom Helm, London, England. pp. 61-72. 
Greene, C. and Kremen, A. 2003. U.S. Organic Farming in 200-2001: Adoption of Certified Systems. U.S. Department of Agriculture, Economic Research Service, Resource Economics Division, Agriculture Information Bulletin No. 780. Washington D.C.

Hanson, James, Robert Dismukes, William Chambers, Catherine Greene, and Amy Kremen. 2004. Risk and Risk Management in Organic Agriculture: Views of Organic Farmers. Renewable Agriculture and Food Systems. 19:218-227.

Hepple, L. W.. 2008. Geography and the pragmatic tradition: The threefold engagement Geoforum 39: 1530-1541

Ikerd, John. 2001. Corporate Agriculture and Family Farms. Presented at National Conference of Block and Bridle. St. Louis Missouri, January 20, 2001.

Irish Organic Farmers and Growers Association Ltd. 2009 Main Street, Newtownforbes, Co.Longford, Tel: (043) 3342495.Email: iofga@eircom.net Web: www.irishorganic.ie

James, W. 1907. Pragmatism: A New Name for Some Old Ways of Thinking. Longman \& Green, New York, N.Y.

Lampkin, N. and S. Padel, eds. 1994. The Economics of Organic Farming: An International Perspective. Wallingford: CAB International.

Lipson, M. 1997. Searching for the "O-Word": Analyzing Current Research Information System for Pertinence to Organic Farming. Santa Cruz CA: Organic Farming Research Foundation.

Light, A. and E. Katz., eds. 1996. Environmental Pragmatism. Routledge, London, England.

Lockeretz, William. 1997. Diversity of Personal and Enterprise Characteristics among Organic Growers in the Northeastern U.S.. Biological Agriculture and Horticulture 14:13-24.

Lohr, Luanne and Timothy Park. 2003. Improving Extension Effectiveness for Organic Clients: Current Status and Future Directions. Journal of Agriculture and Resource Economics 28(3):634-650.

Lotter, Donald. 2003. Organic Agriculture. Journal of Sustainable Agriculture 21(4) 59-128.

Mäder, Paul, Andreas Fließbach, David Dubois, Lucie Gunst, Padruot Fried, and Urs Niggli. 2002."Soil Fertility and Biodiversity in Organic Farming. ” Science 296, no. 5573: 169497. 
Mccann, Elizabeth, Shannon Sullivan, Donna Erickson, and Raymond De Young. 1997. Environmental Awareness, Economic Orientation, and Farming Practices: A Comparison of Organic and Conventional Farmers. Environmental Management 21(5): 747-758.

Oehler, K., ed. 1968. How to Make Our Ideas Clear (Über die Klarheit Unserer Gedanken) By Charles Peirce. V. Klosterman, Frankfurt, Germany.

Organic Centre. 2009. http://www.theorganiccentre.ie/

Organic Europe. Europe and EU. http://www.organic-europe.net/

Forschungsinstitut fuer biologischen Landbau (FiBL), Research Institute of Organic Agriculture, accessed 3 June 2010.

Organic Trust Ltd. 2009.

Vernon House, 2 Vernon Avenue, Clontarf Dublin 3. Tel: (01) 853 0271.Email: organic@iol.ie. Web: http://www.organic-trust.org/

Organic World. 2009. Graph: Agricultural land and producers. http://www.organicworld.net/statistics-europe-land-producers.html, accessed 3 June 2010.

Padel, Susanne. 2001. Conversion to Organic Farming: A Typical Example of the Diffusion of an Innovation? Sociologia Ruralis 41(1): 40-61.

Padel, S. 2008. 'Values of organic producers converting at different times: results of a focus group study in five European countries', Int. J. Agricultural Resources, Governance and Ecology, Vol. 7, Nos. 1/2, pp.63-77.

RTÉ. 23 February 2010. http://www.rte.ie/news/2010/0223/sargenttstatement.html

Reganold, John P., Preston K. Andrews, Jennifer R. Reeve, Lynne Carpenter-Boggs, Christopher W. Schadt, J. Richard Alldredge, Carolyn F. Ross, Neal M. Davies, Jizhong. 2010. Fruit and Soil Quality of Organic and Conventional Strawberry Agroecosystems. PLoS ONE. http://www.plosone.org/article/info\%3Adoi\%2F10.1371\%2Fjournal.pone.0012346

Rigby, Dan and D. Cáceres. 2001. Organic Farming and the Sustainability of Agricultural Systems. Agricultural Systems 68:21-40.

Teagasc. 2008. Guidelines for Organic Farming. Agriculture and Food Development Authroity. Oak Park, County Carlow, Ireland. www.teagasc.ie.

Thayer, H.S. 1970. Pragmatism: The Classic Writings. New American Library, New York, N.Y.

USDA. 2009. National Organic Programme. United States Department of Agriculture. http://www.ams.usda.gov/AMSv1.0/nop 
Walz, Erica. 1999. Final Results of the Third Biennial National Organic Farmers' Survey, Santa Cruz CA: Organic Farming Research Foundation. 126 pp.

White, G.F. 1972. Geography and public policy. Professional Geographer 24(2):101-104.

Wescoat, J.L. 1992. Common themes in the work of Gilbert White and John Dewey: a pragmatic appraisal. Annals of the Association of American Geographers 82(4):587-607.

Wescoat, J.L. 1987. The 'practical range of choice' in water resources geography. Progress in Human Geography 11:41-59.

Willer, Helga and Lukas Kilcher (Eds.) 2009. The World of Organic Agriculture. Statistics and Emerging Trends 2009. FIBL-IFOAM Report. IFOAM, Bonn; FiBL, Frick; ITC, Geneva.

Wood, N. and S. Smith. 2008. Pragmatism and Geography, Editorial. Geoforum 29: 1527-1529. 
Table 1. Framework to Assess Organic Agricultural Support

I. Leadership

Vision/Goals

Advisery Board

Inter-agency Collaboration

II. Policy

Legislation

Enforcement

Monitor National rules

Meet EU/international policies

Monitor progress

\section{Research}

University

Extension

Grants

On-farm

Farmer initiated

\section{Technical Support}

Organic specialist

Certification process

Evaluate organic option

Develop business plan

Conversion programmes

Training

Farm plans

\section{Financial Support}

Support by acreage

Conversion period

Certification cost share

Loan programmes

Grants

Insurance

VI. Marketing and Promotion

Research consumers

Assist market strategies

Trade shows

Local, Domestic, International

Distributors List
VII. Education and Information

Website

Workshops

Courses/Field Days

Written Material

Mentor Programme

Display or Demo Plots

Certification Information

List of accredited certifiers

Information network

\section{Future Developments}


Use this for level one headings in your article

First paragraph style

Follow-on paragraph style

Use this for level two headings in your article

Use this for level three headings in your article

Use this for level four headings in your article. Text runs on

Displayed quotations (40 words or more)

(1) For numbered lists

- For bulleted lists

Equations

Acknowledgements

Table 1. Your title here.

Figure 1. Your title here.

1. This is a note.

2. This is another note.

Short biographical notes on all contributors

References 